\title{
RESEARCH IN SPORT \\ PHYSICAI A TII \\ Effect of Prolonged exercise, With and Without Axial Impact, on Blood-Brain Barrier Leakage and on Peripheral Markers of Central Fatigue
}

Autor(es): $\quad$ Chupel, Uba; Teixeira, Ana; Massart, Alain; Filaire, Edit

Publicado por: Imprensa da Universidade de Coimbra

URL persistente:

URI:http://hdl.handle.net/10316.2/28380

DOI:

DOI:http://dx.doi.org/10.14195/2182-7087_4_10

Accessed : $\quad$ 26-Apr-2023 12:00:52

A navegação consulta e descarregamento dos títulos inseridos nas Bibliotecas Digitais UC Digitalis, UC Pombalina e UC Impactum, pressupõem a aceitação plena e sem reservas dos Termos e Condições de Uso destas Bibliotecas Digitais, disponíveis em https://digitalis.uc.pt/pt-pt/termos.

Conforme exposto nos referidos Termos e Condições de Uso, o descarregamento de títulos de acesso restrito requer uma licença válida de autorização devendo o utilizador aceder ao(s) documento(s) a partir de um endereço de IP da instituição detentora da supramencionada licença.

Ao utilizador é apenas permitido o descarregamento para uso pessoal, pelo que o emprego do(s) título(s) descarregado(s) para outro fim, designadamente comercial, carece de autorização do respetivo autor ou editor da obra.

Na medida em que todas as obras da UC Digitalis se encontram protegidas pelo Código do Direito de Autor e Direitos Conexos e demais legislação aplicável, toda a cópia, parcial ou total, deste documento, nos casos em que é legalmente admitida, deverá conter ou fazer-se acompanhar por este aviso. 

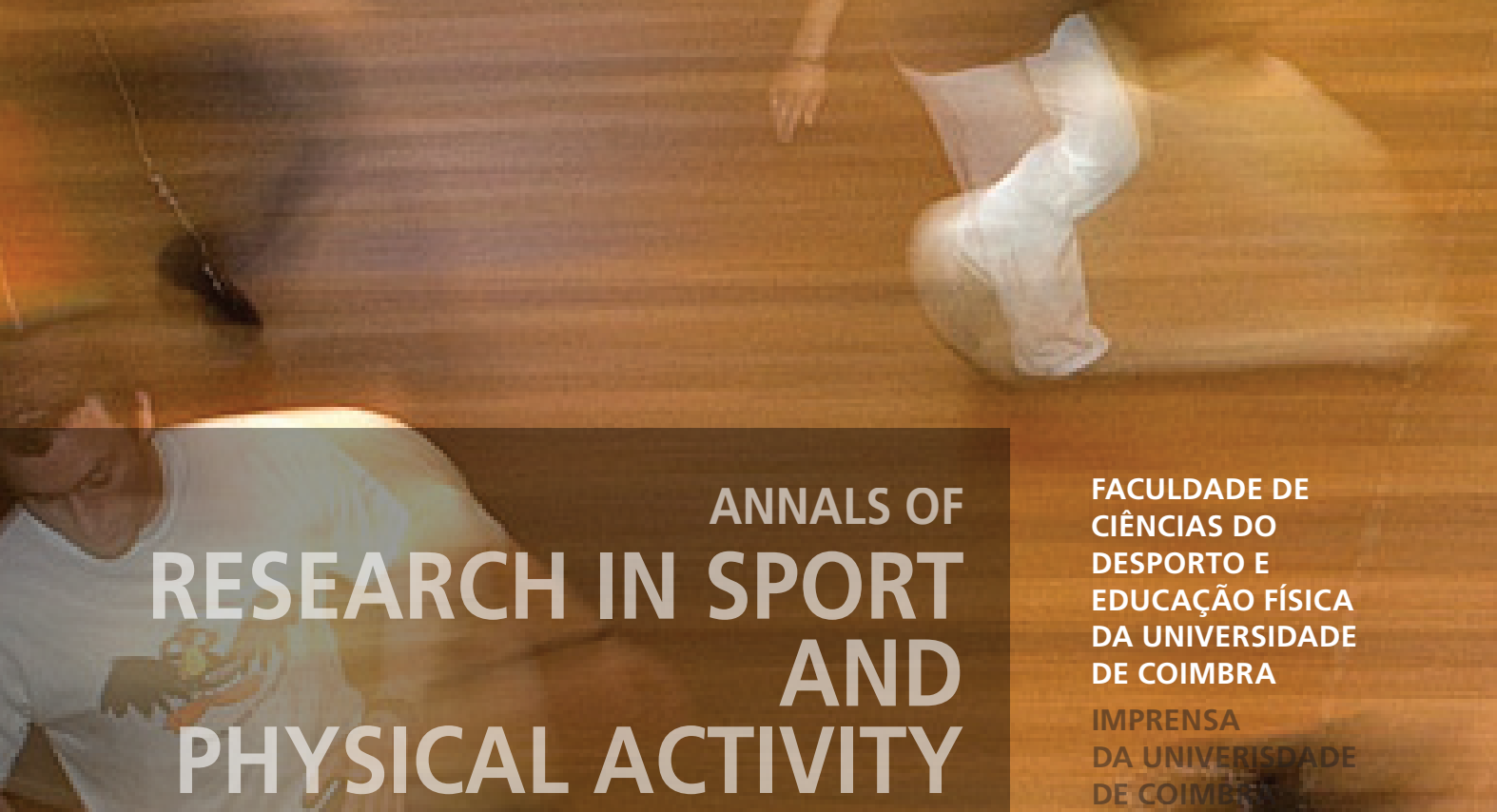
2・TREINO DESPORTIVO/SPORT TRAINING EFFECT OF PROLONGED EXERCISE, WITH AND WITHOUT AXIAL IMPACT, ON BLOOD-BRAIN BARRIER LEAKAGE AND ON PERIPHERAL MARKERS OF CENTRAL FATIGUE 
Uba Chupel', Ana Teixeira', Alain Massart', Edit Filaire².

\section{BACKGROUND}

The synthesis of monoamines and catecholamines in the brain have very important roles during prolonged exercise. In this case, the major activity of the serotonergic system has been connected with the phenomenon of central fatigue and, currently, it is acknowledged that the blood-brain barrier plays a key role in the interaction between the transport of precursors and the synthesis of neurotransmitters. Studies have also pointed out that the structure of the blood-brain barrier can be compromised during the practice of some exercises, however, it is still necessary to see if these changes are able to modulate the activity of the serotonergic system during activity. The aim of this study was to verify the existing associations between blood-brain barrier leakage and peripheral markers of central fatigue induced by prolonged exercise.

\section{METHODS}

Eight trained male triathletes $(n=8)$ with a mean age of $19.87 \pm 2.29$ years conducted two protocols in the same relative intensity of effort. The continuous, prolonged exercise (40 minutes) was conducted in 75\% of VO2max in cycle ergometer at first and, later in the run. Blood and saliva samples were collected, before and after each protocol for examination of S100-B, Prolactin, Cortisol and DHEA.

\section{RESULTS}

The mean value of the salivary cortisol did not show significantly differences between basal and after exercise at both protocols. DHEA exhibited a significantly increase after cycle ergometer $(p=0.012)$ and run $(p=0.025)$. The mean value of $\$ 100-B$ in serum did not show significant changes in any of the experimental situations. However, prolactin increased significantly after the race $(p=0.012)$, and a subtle but not significant increase was observed after cycling $(p=0.123)$. No correlation was observed between these biochemical parameters

\footnotetext{
${ }^{1}$ Faculty of Sport Science and Physical Education - University of Coimbra - Portugal

2 UFRSTAPS - Université Orléans - France
} 
before or after exercise. Ratings of Perceived Exertion (RPE) showed an increase slightly greater occurred on bicycle compared to run.

\section{CONCLUSION}

the S100-B serum levels (injury marker in the blood-brain barrier), were not different between the exercises involving axial impact (run) and cycling (no impact). Accordingly, we suggest that the protocols used (mainly the run) produced significant effects on markers of central fatigue, without interfering in the permeability of the blood-brain barrier. 